\title{
Using light fraction and macroaggregate associated organic matters as early indicators for management-induced changes in soil chemical and biological properties in adjacent native and plantation forests of subtropical Australia
}

\author{
Yan He ${ }^{\mathrm{a}, \mathrm{b}, \mathrm{c}}$, Zhihong Xu ${ }^{\mathrm{b}, *}$, Chengrong Chen ${ }^{\mathrm{b}}$, Joanne Burton ${ }^{\mathrm{b}}$, Qi Ma ${ }^{\mathrm{b}}$, Yuan Ge ${ }^{\mathrm{b}, \mathrm{d}}$, Jianming Xu ${ }^{\mathrm{a}, \mathrm{c}, *}$ \\ a College of Environmental and Natural Resource Sciences, Zhejiang University, Hangzhou 310029, China \\ ${ }^{\mathrm{b}}$ Centre for Forestry and Horticultural Research, Griffith University, Nathan, Brisbane, Queenland 4111, Australia \\ c Zhejiang Provincial Key Laboratory of Subtropical Soil and Plant Nutrition, Hangzhou 310029, China \\ d State Key Laboratory of Urban and Regional Ecology, Research Center for Eco-Environmental Sciences, Chinese Academy of Sciences, Beijing 100085, China
}

\section{A R T I C L E I N F O}

\section{Article history:}

Received 14 March 2008

Received in revised form 18 July 2008

Accepted 11 August 2008

Available online 10 September 2008

\section{Keywords:}

Soil organic matter (SOM) fractions

Light fraction (LF)

Aggregate

Land use and management

Forest

Soil chemical and biological processes

\begin{abstract}
A B S T R A C T
Soil physical structure causes differential accessibility of soil organic matter (SOM), including carbon (C) and nitrogen $(\mathrm{N})$ pools, to decomposer organisms and is an important determinant of SOM storage. Physical fractionation method of SOM in conjunction with elemental as well as isotopic analyses $\left(\mathrm{C}, \mathrm{N}, \delta^{13} \mathrm{C}, \delta^{15} \mathrm{~N}\right)$ of those soil fractions are used in this study to determine the land use and management-induced changes of SOM and associated processes in three adjacent sites of native forest (NF), first (1R) and second rotation (2R, including tree planting row (2R-T) and windrow of harvest residues $(2 \mathrm{R}-\mathrm{W})$ ) of hoop pine plantations in southeast Queensland, Australia. The results suggest that there is a greater accumulation of $C$ and $N$ in the light fraction (LF) of NF site than that of plantation sites (1R and $2 \mathrm{R}$ ), and the $\mathrm{C}$ and $\mathrm{N}$ losses following conversion from mixed species $\mathrm{NF}$ to the single-species plantation are attributed to the reduction in $\mathrm{C}$ and $\mathrm{N}$ stocks for all physical fractions separated by wet sieving. In contrast, the $\mathrm{C}$ and $\mathrm{N}$ losses induced by the rotation practices (e.g., between $1 \mathrm{R}$ and $2 \mathrm{R}-\mathrm{T}$ ) are attributed to the $\mathrm{C}$ and $\mathrm{N}$ decreases in the $\mathrm{LF}$ and macroaggregates $(250-2000 \mu \mathrm{m})$ only. The $C$ and $N$ increases upon the residue management (e.g., between 2R-W and 2R-T) are primarily attributed to the $\mathrm{C}$ and $\mathrm{N}$ increases in the LF and macroaggregates as well. Coupled with 30 soil chemical and biological parameters obtained in our previous studies, further principal component and multivariable regression analyses were conducted and the results showed that both the LF and macroaggregates were highly related to the status of $\mathrm{C}$ and $\mathrm{N}$ pools, the processes of $\mathrm{N}$ transformation and soil respiration, and the diversity of microbial communities, and thus could serve as diagnostic SOM fractions responsible for the changes of soil properties and processes within the tested ecosystem induced by the land uses and management practices. Knowledge of the interactive relationships between aggregate classes within SOM and soil chemical and biological processes in this study represents a further step towards diagnostically measuring and understanding important soil $\mathrm{C}$ and $\mathrm{N}$ processes in response to the land use and management changes in the soil ecosystems such as forests in subtropical Australia.
\end{abstract}

(C) 2008 Elsevier B.V. All rights reserved.

\section{Introduction}

Soil organic matter (SOM) influences soil chemical and biological properties that control nutrient cycling and consequently has a major effect on forest productivity and sustainability. Due to the important role of SOM in nutrient cycling, there has long been an interest in understanding how forest soil management affects SOM pools (Johnson and Curtis, 2001; Echeverría et al., 2004; Blumfield et al., 2004; Xu and

\footnotetext{
* Corresponding authors. Centre for Forestry and Horticultural Research, Griffith University, Nathan, Brisbane, Queenland 4111, Australia; College of Environmental and Natural Resource Sciences, Zhejiang University, Hangzhou 310029, China. Tel.: +61 7 37353822.

E-mail addresses: zhihong.xu@griffith.edu.au (Z.Xu), jmxu@zju.edu.cn (J. Xu).
}

Chen, 2006). However, because SOM exists throughout the soil matrix in a variety of different sizes, shapes, levels of degradation, and degrees of association with soil minerals, the positions of SOM with respect to the pores and aggregated structures can cause differential accessibility to decomposers, and result in a range of SOM fractions that differ in stability and dynamics (Ladd et al., 1993). Accordingly, the role of soil physical structure as a determinant of SOM sequestration has attracted much interest over the past two decades (Ladd et al., 1993; Christensen, 2001; Six et al., 2004; Ni et al., 2004).

Analyses of soil physical structure are usually conducted using physical fractionation methods, which are based on the premise that the association of the primary soil particles and their spatial arrangement play a key role in the function of SOM (Gregorich et al., 2006). To date, physical fractionation of SOM has been found to be 
useful for identifying the physical control of SOM, characterizing the relationship between SOM and size distribution of aggregates, and elucidating soil processes and mechanisms involved in the dynamics of SOM (Cambardella and Elliott, 1993; Six et al., 2002; Lützow et al., 2007). Also, it has been established that physical fractionation techniques can augment the detection limits for SOM dynamics by isolating SOM pools more sensitive to changes in land use and management (Six et al., 2002), and thus has been widely utilized to distinguish specific carbon $(\mathrm{C})$ and nitrogen $(\mathrm{N})$ pools responsive to land use and management (Elliott, 1986; Jastrow, 1996; Christensen, 2001; Six et al., 2002; Jolivet et al., 2003). For instance, studies assessing land use and cultivation practice impacts on soil have successfully used shifts in macroaggregate associated SOM to document indirectly but sensitively changes in soil $\mathrm{C}$ and $\mathrm{N}$ cycling dynamics (Franzluebbers and Arshad, 1997; Puget et al., 2000). Particulate organic matter (POM) that was biologically labile from aggregate entrapped material was found to be capable as an index of soil $\mathrm{C}$ and $\mathrm{N}$ dynamics in an ecosystem under different tillage practices (Wander and Bidart, 2000). However, ideally a sensitive diagnostic SOM functional pool responsible for the land use and management changes would reflect physical, chemical, and biological aspects of the soil simultaneously, such as rates of soil $\mathrm{C}$ and $\mathrm{N}$ mineralization, and the shift in soil microbial community, rather than providing only static measures of SOM pools. Elucidation of the interactive relationships between different SOM functional pools and the corresponding soil chemical and biological processes are warranted for improved research into land use and management issues of forests.

Extensive conversion of multiple species of native forest (NF) into single-species plantation forests, such as hoop pine (Araucaria cunninghamii) plantation, is one of the most wide spread changes in land use in Australia, in order to meet the ever-growing demand for timber. For the long-term sustainability and productivity of forest plantations, great efforts have been made in understanding the impact of different land uses and forest management, and recent studies have revealed that changes regarding the nutrient dynamics and chemical properties of soils occurred following the land use conversion from NF to hoop pine plantations (Chen et al., 2004; Burton et al., 2007a,b; Burton, 2007c). For an improved understanding, a more fundamental, SOM pool-involved investigation is warranted considering the important controlling role that SOM would serve in the chemical and biological processes of soil.

This study represents the first effort toward improving knowledge for land use and management issues of forests by fractionating SOM into different meaningful pools and assessing their interactions with soil physical, chemical, and biological aspects simultaneously. Selecting as the study area three well-studied adjacent NF and hoop pine plantation forest sites that exhibited different responses in soil chemical and biological processes to different forest type, rotation practices and residue management, our objectives were (1) to investigate the role of soil physical structure in $\mathrm{C}$ and $\mathrm{N}$ sequestration, and (2) to develop sensitive diagnostic SOM fractions associated with changes of soil chemical and biological processes in forest ecosystems under different land use and management practices. We hypothesized that land use and management-induced changes in soil chemical and biological processes would be predominantly reflected by parallel changes in the expected responsible SOM fractions.

\section{Materials and methods}

\subsection{Site description and sample collection}

The NF and hoop pine plantation study sites were located in Yarraman State Forest, southeast Queensland, Australia $\left(26^{\circ} 52^{\prime} \mathrm{S}\right.$, $151^{\circ} 51^{\prime} \mathrm{E}$ ). Details of the study area were provided by Chen et al. (2004) and Burton et al. (2007a). In brief, the climate is subtropical with a variable annual rainfall (range: $433-1110 \mathrm{~mm}$ ) and a long-term mean rainfall of $816 \mathrm{~mm}$ per annum. The soil was a Typic Durustalf (Soil Survey Staff, 1999), with a clayey texture (Chen et al., 2004). The NF site is classified as a mixed rainforest/scrub and is dominated by bunya pine (Araucaria bidwilli Hook.), yellowwood (Terminalia oblongata F. Muell. Subsp. Oblongata), crows ash (Pentaceras australis R.B) and lignum-vitae (Premna lignum-vitae), with emergent hoop pine (Araucaria cunninghamii Aiton ex A. Cunn.). Three experimental sites measuring 0.2 ha in area, with at least $100 \mathrm{~m}$ interval between each other as buffer area for edge effect-avoiding purpose, were located in NF, first rotation (1R) and second rotation (2R) hoop pine plantation. The $1 \mathrm{R}$ plantation was established and converted from NF in 1952. The $2 \mathrm{R}$ hoop pine was planted in 2000 after the clearcut harvest of part of the $1 \mathrm{R}$ plantation in 1999. Post harvest residues from the $1 \mathrm{R}$ plantation were formed into windrows approximately $6 \mathrm{~m}$ apart, using a D6 bulldozer with shear blade, and areas between windrows were then used as tree planting rows for the $2 \mathrm{R}$ plantation. Hence, the three NF, $1 \mathrm{R}$ and $2 \mathrm{R}$ hoop pine plantation areas are adjacent to each other, and the $2 \mathrm{R}$ plantation area was divided into the following two treatments based on the residue management practices, (1) tree planting row (2R-T) and (2) windrow of harvest residues $(2 \mathrm{R}-\mathrm{W})$. The $1 \mathrm{R}$ hoop pine plantation was approximately 53 years old and the $2 \mathrm{R}$ hoop pine plantation 5 years old when soil was sampled in 2005.

Each of the four treatments was divided into five $24 \mathrm{~m}^{2}$ subplots for soil sampling. Litter and fermentation layer samples were removed before soil collection. Fifteen soil cores $(0-10 \mathrm{~cm})$ were randomly collected from each of the five replicate subplots per treatment using a $7.5 \mathrm{~cm}$ diameter auger and bulked. Five mixed samples from the corresponding five subplots finally yielded the five replicates for the four NF, 1R, and 2R-T and 2R-W treatments, respectively. Humus layer was not clearly distinguished in either the NF or plantation forests. All samples were transported to the laboratory where field moist soils were well mixed and passed through a $<2 \mathrm{~mm}$ sieve (roots were separated from soil during sieving) and stored at $4{ }^{\circ} \mathrm{C}$ until further analysis.

\subsection{Fractionation of light fraction and water stable aggregates}

The fractionation was conducted with a modification according to the wet-sieving procedure suggested by Elliott (1986) and Tan et al. (2007). In brief, $200 \mathrm{~g}$ samples of air-dried bulk soil (passing a $2 \mathrm{~mm}$ sieve) was placed on the top of a set of nested sieves (250,53 $\mu \mathrm{m})$. Samples were soaked in deionized water for $10 \mathrm{~min}$ to allow slaking. Organic debris and root pieces that floated in the water (density $<1.0 \mathrm{~g}$ $\mathrm{cm}^{-3}$ ) were collected onto a $38 \mu \mathrm{m}$ nylon filter. This material was quantified as the free light fraction (LF) and considered to be the litter component of whole soil C. After the collection of LF, the nested sieves were gently oscillated ( $5 \mathrm{~cm}$ amplitude of 25 strokes $\mathrm{min}^{-1}$, using a custom-made sieving machine) within a column of water for $30 \mathrm{~min}$. The $<53 \mu \mathrm{m}$ fraction was collected by sedimentation for $48 \mathrm{~h}$. Silt and clay particles in the supernatant were precipitated with $0.25 \mathrm{M} \mathrm{CaCl}_{2}+$ $0.25 \mathrm{M} \mathrm{MgCl}_{2}$ and the precipitate was combined with the $<53 \mu \mathrm{m}$ fraction. Aggregate fractions were then recovered and dried at $40{ }^{\circ} \mathrm{C}$ to constant moisture contents.

Ultimately, we obtained four fractions: the LF with density $<1.0 \mathrm{~g} \mathrm{~cm}^{-3}$, macroaggregates (250-2000 $\mu \mathrm{m})$, microaggregates $(53-250 \mu \mathrm{m})$, and silt and clay fraction $(<53 \mu \mathrm{m})$. It is noted that all of these fractions contained not only soil aggregates of different size but also free particulate organic matter of different sizes, some primary sand grains (sieve fractions $>53 \mu \mathrm{m}$ ), and, in the case of the $<53 \mu \mathrm{m}$ fraction, also non-aggregated silt and clay particles.

\subsection{Elemental and isotopic analysis}

Soil fractions were analysed for $\mathrm{C}$ and $\mathrm{N}$ isotopic compositions $\left(\delta^{13} \mathrm{C}, \delta^{15} \mathrm{~N}\right)$, and total $\mathrm{C}$ and $\mathrm{N}$ contents using a Eurovector Elemental Analyser (EuroEA 3000, Milan, Italy) interfaced with a Delta Plus 
isotope ratio mass spectrometer (GV Isoprime, Manchester, UK) operating in continuous flow mode. Carbon and $\mathrm{N}$ isotope ratios are presented in $\delta$ notation:

$\delta=\left[\left(R_{\mathrm{SAMPLE}}-R_{\mathrm{STD}}\right) / R_{\mathrm{STD}}\right] \times 10^{3}$

where $R_{\text {SAMPLE }}$ is the ${ }^{13} \mathrm{C} /{ }^{12} \mathrm{C}$ or ${ }^{15} \mathrm{~N} /{ }^{14} \mathrm{~N}$ ratio of the sample and $R_{\text {STD }}$ is the ${ }^{13} \mathrm{C} /{ }^{12} \mathrm{C}$ ratio of the V-PDB standard or ${ }^{15} \mathrm{~N} /{ }^{14} \mathrm{~N}$ ratio of atmospheric $\mathrm{N}_{2}$. Precision of measurements was $0.1 \%$ for $\delta^{13} \mathrm{C}$ and $0.2 \%$ 。 for $\delta^{15} \mathrm{~N}$.

\subsection{Soil chemical and biological properties}

Our previous studies have shown that consistent significant differences occurred with respect to soil chemical and biological properties following the conversion of NF to hoop pine plantations (Chen et al., 2004; Burton et al., 2007a,b). In general, the soil under NF contained higher C (mean $91.30 \mathrm{~g} \mathrm{~kg}^{-1}$ ) and $\mathrm{N}$ (mean $8.1 \mathrm{~g} \mathrm{~kg}^{-1}$ ) compared with hoop pine plantations (averaged $64.73 \mathrm{~g} \mathrm{~kg}^{-1}$ and $5.36 \mathrm{~g} \mathrm{~kg}^{-1}$ each for $\mathrm{C}$ and $\mathrm{N}$, respectively). Other basic chemical characteristics such as CEC and $\mathrm{pH}$ ranged from $36.5-56.9 \mathrm{cmol}(+) \mathrm{kg}^{-1}$ and $6.0-6.6$, respectively. All soils contained $36.0-48.4 \%$ clay, $18.9-30.6 \%$ silt and $27.8-33.4 \%$ sand (Burton, 2007c).

From the above studies, we referred to 30 soil chemical and biological parameters (categorized in the form of $\mathrm{C}$ pool, $\mathrm{N}$ pool, $\mathrm{N}$ transformation, and microbial diversity and soil respiration related indexes) and conducted principal component and multivariable regression analyses to help identify the sensitive fraction parameters accounting for the changes observed following the changes in land uses and management. In brief, total $\mathrm{C}$ and $\mathrm{N}$ were analysed as above; microbial biomass $\mathrm{C}$ and $\mathrm{N}$ were measured using the fumigationextraction method (Vance et al., 1987); soluble organic C and $\mathrm{N}$ were measured from the soil extracts using $70{ }^{\circ} \mathrm{C}$ hot water, and $100{ }^{\circ} \mathrm{C}$ hot $2 \mathrm{M} \mathrm{KCl}$ and $0.5 \mathrm{M} \mathrm{K}_{2} \mathrm{SO}_{4}$, respectively (Gianello and Bremner, 1986; Wang et al., 2001; Chen et al., 2005); net $\mathrm{N}$ mineralization and nitrification were determined in a 3-day incubation using the ${ }^{15} \mathrm{~N}$ pool dilution method (Hart et al., 1994); potential production of soluble organic $\mathrm{N}$ was calculated based on a 7-day anaerobic incubation (Burton et al., 2007b); soil basal respiration was determined in a 28day aerobic incubation (Chen et al., 2000); C source substrate induced respiration and utilization patterns were assessed using both Biolog ${ }^{\mathrm{TM}}$ and MicroResp ${ }^{\mathrm{TM}}$ techniques (Widmer et al., 2001; Campbell et al., 2003). More detailed information can be found in the previous studies of Burton et al. (2007a,b) and Burton (2007c).

\subsection{Statistical analysis}

Statistical analysis was conducted with the SPSS 13.0 GLM, UNIVARIATE, REGRESSION and FACTOR procedures. We acknowledge that pseudo-replication is a limitation of the present study, as in many other paired-site and chronosequence studies (Sá et al., 2001; Vesterdal et al., 2002; O'Brien et al., 2003; Chen et al., 2004). Since each stand within a given region was separated by at least $100 \mathrm{~m}$, we believe that the treatment effects are almost certainly more substantial than any possible site differences, given the severity of the treatments. And thus a valid statistical ANOVA was warranted. One-way ANOVA between NF and $1 \mathrm{R}$, and $1 \mathrm{R}$ and $2 \mathrm{R}$-T was carried out for all data on SOM fraction properties. All data were checked and Log transformed where appropriate for normality before ANOVA. Multiple comparisons (least significant difference) were used to separate the means when differences were significant. Paired $t$-test was used for the comparison between $2 \mathrm{R}-\mathrm{T}$ and $2 \mathrm{R}-\mathrm{W}$. Multivariate analysis was conducted to distinguish groups of the tested sites and define characteristics responsible for group separation. Simultaneous observations of 20 variables were tested by principle component analysis (PCA). These variables used for PCA represented both quantity and quality of the four different SOM physical fractions. The number of components was determined by the eigenvalue-one criterion (Kaiser,
1960) and scree test (Cattell, 1966). All meaningful loadings (i.e. $>0.40$ ) were included in the interpretation of the PC. Principal components that explained more than $5 \%$ of the total variance were considered to be significant. Identification of the interactive effects of SOM fractions on soil chemical and biological parameters were further performed using stepwise regression analysis. The significance level to enter the model was 0.50 , and the significance level to stay in the model was 0.05 . Results from all four forest systems with five replicates were included in that analysis to allow us to investigate fraction sensitivity to land use and management changes. Collinearity between independent variables was evaluated using the condition index (Marriott and Wander, 2006). In all cases, the condition index was $<30$, indicating that moderate or severe collinearity was not a problem.

\section{Results}

\subsection{Total mass, $C$ and $N$ recovery after fractionation}

The percentage of total mass recovered in the sum of the four fractions ranged from 98.5\% to 99.5\% (mean 99.0\%) (data not shown). Carbon and $\mathrm{N}$ recovered in the sum of the fractions were similarly consistent, ranging from $95.9 \%$ to $96.8 \%$ (mean $96.3 \%$ ) for C, and from $102.3 \%$ to $106.9 \%$ (mean $104.5 \%$ ) for N (data not shown), respectively.

In general, mass balance calculations revealed that less than $4.25 \%$ of the original bulk soil C content was mobilized and subsequently discarded during physical fractionation for all soils. The $\mathrm{N}$ balance after fractionation however, expressed as the ratio of the sum of fraction $\mathrm{N}$ to whole soil $\mathrm{N}$, was generally $>1(1.04 \pm 0.06)$. We attributed this to the systematic and analytical errors during the whole wet sieving and subsequent analysis procedure.
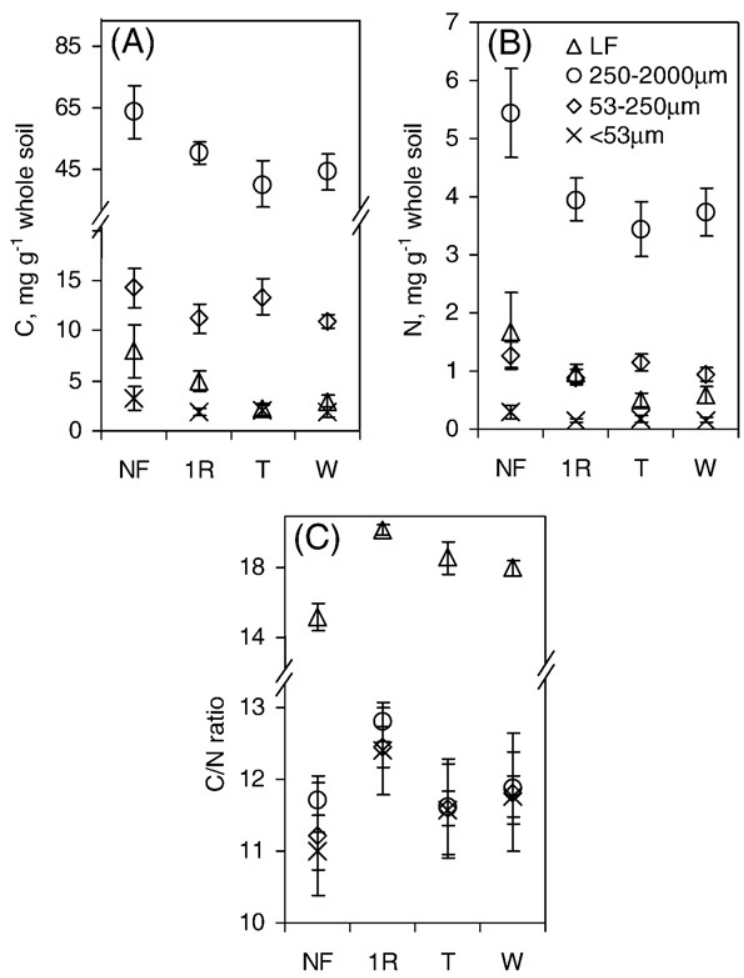

Fig. 1. SOM status with total $C(A)$, total $N(B)$ and $C / N$ ratio $(C)$ in the light fraction, macroaggregates $(250-2000 \mu \mathrm{m})$, microaggregates $(53-250 \mu \mathrm{m})$ and silt and clay fraction $(<53 \mu \mathrm{m})$ separated from the adjacent native forest and hoop pine plantation forest sites. Each point represents the mean of five replicates. Error bars are standard errors of the mean. NF, native forest; $1 \mathrm{R}$, first rotation of hoop pine plantation; $T$, tree planting row in the second rotation of hoop pine plantation; and $\mathrm{W}$, windrow of harvest residues in the second rotation of hoop pine plantation. 
Table 1

Statistical results for analysis of land use and forest management-induced effects on fraction parameters of soil organic matter

\begin{tabular}{|c|c|c|c|c|}
\hline \multirow[t]{3}{*}{ Independent variable } & \multicolumn{4}{|c|}{ Dependent variable $^{a}$} \\
\hline & $\mathrm{LF}$ & $250-2000 \mu \mathrm{m}$ & $53-250 \mu \mathrm{m}$ & $<53 \mu \mathrm{m}$ \\
\hline & \multicolumn{4}{|c|}{$F$ or $T$ value $^{b}$} \\
\hline \multicolumn{5}{|l|}{ C } \\
\hline$N F / 1 R^{c}$ & $6.03^{*}$ & $10.16^{*}$ & $8.09^{*}$ & $6.55^{*}$ \\
\hline 1R/2R-T & $27.45^{* * *}$ & $7.26^{*}$ & ns & ns \\
\hline $2 \mathrm{R}-\mathrm{T} / 2 \mathrm{R}-\mathrm{W}$ & ns & ns & $2.74^{*}$ & ns \\
\hline \multicolumn{5}{|l|}{$\mathrm{N}$} \\
\hline $\mathrm{NF} / 1 \mathrm{R}$ & $5.54^{*}$ & $15.58^{* *}$ & $11.10^{*}$ & $8.60^{*}$ \\
\hline $1 \mathrm{R} / 2 \mathrm{R}-\mathrm{T}$ & $29.14^{* * *}$ & ns & $9.80^{*}$ & ns \\
\hline 2R-T/2R-W & ns & ns & $2.77^{*}$ & ns \\
\hline \multicolumn{5}{|l|}{$\delta^{13} \mathrm{C}$} \\
\hline $\mathrm{NF} / 1 \mathrm{R}$ & $11.06^{*}$ & ns & ns & ns \\
\hline 1R/2R-T & $6.43^{*}$ & ns & ns & ns \\
\hline $2 \mathrm{R}-\mathrm{T} / 2 \mathrm{R}-\mathrm{W}$ & ns & ns & ns & ns \\
\hline \multicolumn{5}{|l|}{$\delta^{15} \mathrm{~N}$} \\
\hline $\mathrm{NF} / 1 \mathrm{R}$ & $5.39^{*}$ & ns & ns & ns \\
\hline $1 \mathrm{R} / 2 \mathrm{R}-\mathrm{T}$ & ns & ns & ns & ns \\
\hline 2R-T/2R-W & ns & ns & ns & ns \\
\hline \multicolumn{5}{|l|}{$\mathrm{C} / \mathrm{N}$ ratio } \\
\hline $\mathrm{NF} / 1 \mathrm{R}$ & $175.70^{* * *}$ & $44.34^{* * *}$ & $10.00^{*}$ & $22.63^{* *}$ \\
\hline 1R/2R-T & $13.44^{* *}$ & $13.16^{* *}$ & $27.53^{* * *}$ & ns \\
\hline $2 \mathrm{R}-\mathrm{T} / 2 \mathrm{R}-\mathrm{W}$ & ns & ns & ns & ns \\
\hline
\end{tabular}

*** $* * *$ significant at the $0.001,0.01$ and 0.05 probability level, respectively.

a LF, light fraction; 250-2000 $\mu \mathrm{m}, 250-2000 \mu \mathrm{m}$ size macroaggregate fraction; 53$250 \mu \mathrm{m}, 53-250 \mu \mathrm{m}$ size microaggregate fraction; $<53 \mu \mathrm{m},<53 \mu \mathrm{m}$ size silt and clay fraction; ns, not significant $(p>0.05)$.

b $F$ values for comparison between NF and $1 \mathrm{R}$, and $1 \mathrm{R}$ and $2 \mathrm{R}-\mathrm{T} ; \mathrm{T}$ values for comparison between $2 \mathrm{R}-\mathrm{T}$ and $2 \mathrm{R}-\mathrm{W}$.

c NF, native forest; $1 \mathrm{R}$, first rotation of hoop pine plantation; 2R-T, tree planting row in the second rotation of hoop pine plantation; and 2R-W, windrow of harvest residues in the second rotation of hoop pine plantation.

\section{2. $C$ and $N$ content and distribution within the fractions}

The $\mathrm{C}$ contents (normalized to the total mass of the whole soil) decreased consistently and significantly $(p \leq 0.05)$ in all physical fractions following the change from NF to $1 \mathrm{R}$ (Fig. 1A, Table 1). For the difference among the other three plantation sites, significant decrease was found in $2 \mathrm{R}-\mathrm{T}$ for the $\mathrm{C}$ associated in the $\mathrm{LF}(F=27.45$, $p<0.001)$ and macroaggregates $(F=7.26, p<0.05)$ if compared to $1 \mathrm{R}$ (Fig. 1A, Table 1). In contrast, this variation pattern exhibited an opposite trend when comparing $2 \mathrm{R}-\mathrm{T}$ to $2 \mathrm{R}-\mathrm{W}$, with significant decreased $C$ associated in microaggregates $(T=2.74, p<0.05)$ after the residues had been windrowed (Fig. 1A, Table 1). Changes of soil $\mathrm{N}$ content among the four fractions paralleled the changes in soil $\mathrm{C}$ content (Fig. 1B, Table 1). Significant differences of $\mathrm{C} / \mathrm{N}$ ratios between
NF and $1 R$, and $1 R$ and $2 R-T(p \leq 0.05)$ were also found in most of the physical fractions observed, except that in the silt and clay fraction between 1R and 2R-T (Fig. 1C, Table 1).

The distribution of $\mathrm{C}$ and $\mathrm{N}$ among all soil fractions (as indicated by the percentage amount of $\mathrm{C}$ and $\mathrm{N}$ compared to the total $\mathrm{C}$ and $\mathrm{N}$ in whole soil) decreased in the following order: macroaggregates $>$ microaggregates $>\mathrm{LF}>$ silt and clay fraction. Macroaggregates were the dominant size fraction for all the treatments, representing more than $66.8 \%$ of the total soil C (TC) and $67.0 \%$ of total soil N (TN). In contrast, approximately $15.8-22.6 \%$ of TC and TN are found in the microaggregates, and $3.5 \%$ to $8.6 \%$ of TC and $9.4 \%$ to $20.3 \%$ of TN are located in the LF. Less than $4 \%$ of both the TC and TN were associated in the silt and clay fraction (calculated from Fig. 1A and B). Meanwhile, greater correlation coefficients of TC and TN were found with the macroaggregates and LF associated $C$ and $N\left(R_{C}=0.938\right.$ and $0.910, R_{N}=0.932$ and $0.892, p<0.001, n=20$, each for the macroaggregates and $\mathrm{LF}$ respectively) than with the microaggregates $\left(R_{\mathrm{C}}=0.257, R_{\mathrm{N}}=0.334\right.$, $p>0.05, n=20)$ and silt and clay fraction $\left(R_{\mathrm{C}}=0.782, R_{\mathrm{N}}=0.775\right.$, $p<0.001, n=20)$. Additionally, the LF for all soils had the largest $C / N$ ratio with a wider range from 15.2 to 20.2 (Fig. 1C). For the other three aggregate-size separates, $\mathrm{C} / \mathrm{N}$ ratio was smallest in the silt and clay fraction and largest in the macroaggregates, with the intermediate value for the microaggregates, presenting a decrease tendency with decreasing size of the fractions (Fig. 1C).

\subsection{Natural abundance of ${ }^{13} \mathrm{C}$ and ${ }^{15} \mathrm{~N}$ in soil fractions}

Despite observing negligible variations in both $\delta^{13} \mathrm{C}$ and $\delta^{15} \mathrm{~N}$ for all the aggregate fractions among the four treatments, significant changes were found in the LF when comparing the differences between NF and 1R (Table 1). Meanwhile, the $\delta^{13} \mathrm{C}$ values in LF were less enriched in the NF than that of the plantation sites, and the $\delta^{15} \mathrm{~N}$ values in LF were highest in the NF in comparison to that in the plantation sites (Fig. 2). Additionally, despite that $\delta^{13} \mathrm{C}$ values were hardly altered subsequent to the plantation, the values of all the fractions exhibited a coincident decreasing tendency when comparing the difference between 2R-T and 2R-W (Fig. 2A). Possible reason might lie on the depletion of soil $C$ in the system induced by decomposition and the accumulation of woody plant-derived $\mathrm{C}$ following windrow residue management.

As for the comparison among fractions, the $\delta^{13} \mathrm{C}$ values of all soil fractions ranged from $-26.78 \%$ to $-25.35 \%$ o and were typical of $\mathrm{C}$ derived from the forest land dominated by $\mathrm{C}_{3}$ species. The lowest $\delta^{13} \mathrm{C}$ values were found in the LF in all soils, representing a labile material of relatively recent origin. The other fractions possessed relatively enriched $\delta^{13} \mathrm{C}$ values, representing older, more humified and amorphous organic compounds (Fig. 2A). With respect to the natural
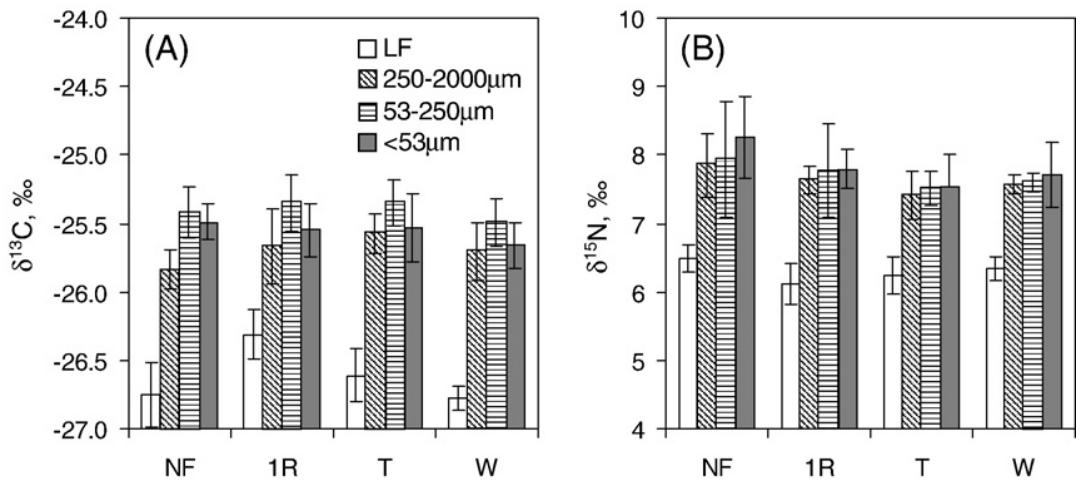

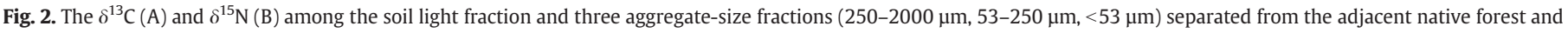

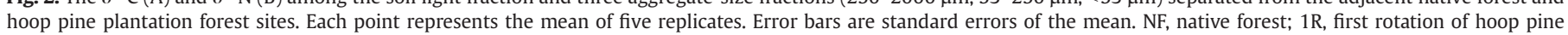
plantation; T, tree planting row in the second rotation of hoop pine plantation; and $\mathrm{W}$, windrow of harvest residues in the second rotation of hoop pine plantation. 
Table 2

Principal component scores based on 20 physical fractionation variables

\begin{tabular}{|c|c|c|c|c|c|}
\hline & \multicolumn{5}{|c|}{ Principal component } \\
\hline & PC1 & PC2 & PC3 & PC4 & PC5 \\
\hline Eigenvalue & 6.73 & 3.29 & 2.94 & 2.77 & 1.36 \\
\hline \multirow[t]{2}{*}{ Proportion (\%) } & 33.66 & 16.45 & 14.71 & 13.87 & 6.81 \\
\hline & \multicolumn{5}{|c|}{ Rotated scores of five retained eigenvectors } \\
\hline $\mathrm{C}_{\mathrm{LF}}$ & 0.945 & & & & \\
\hline $\mathrm{N}_{\mathrm{LF}}$ & 0.935 & & & & \\
\hline$C_{250-2000 \mu \mathrm{m}}$ & 0.926 & & & & \\
\hline $\mathrm{N}_{250-2000 \mu \mathrm{m}}$ & 0.916 & & & & \\
\hline $\mathrm{N}_{<53 \mu \mathrm{m}}$ & 0.814 & & & & \\
\hline $\mathrm{C}_{<53 \mu \mathrm{m}}$ & 0.811 & & & & \\
\hline$\delta^{15} \mathrm{~N}_{<53 \mu \mathrm{m}}$ & 0.687 & & & & 0.472 \\
\hline$\delta^{13} C_{53-250 \mu \mathrm{m}}$ & & 0.899 & & & \\
\hline$\delta^{13} \mathrm{C}_{<53 \mu \mathrm{m}}$ & & 0.865 & & & \\
\hline$\delta^{13} C_{250-2000 \mu \mathrm{m}}$ & & 0.850 & & & \\
\hline $\mathrm{N}_{53-250 \mu \mathrm{m}}$ & & & 0.868 & & \\
\hline $\mathrm{C}_{53-250 \mu \mathrm{m}}$ & & & 0.802 & & \\
\hline $\mathrm{C} / \mathrm{N}_{53-250 \mu \mathrm{m}}$ & & & -0.730 & & \\
\hline$\delta^{13} \mathrm{C}_{\mathrm{LF}}$ & & 0.407 & & 0.847 & \\
\hline $\mathrm{C} / \mathrm{N}_{250-2000 \mu \mathrm{m}}$ & & & -0.545 & 0.712 & \\
\hline $\mathrm{C} / \mathrm{N}_{<53 \mu \mathrm{m}}$ & & -0.415 & & 0.661 & \\
\hline $\mathrm{C} / \mathrm{N}_{\mathrm{LF}}$ & -0.610 & & & 0.621 & \\
\hline$\delta^{15} \mathrm{~N}_{\mathrm{LF}}$ & & & & -0.618 & \\
\hline$\delta^{15} \mathrm{~N}_{250-2000 \mu \mathrm{m}}$ & 0.500 & & & & 0.669 \\
\hline$\delta^{15} \mathrm{~N}_{53-250 \mu \mathrm{m}}$ & 0.413 & & & & 0.547 \\
\hline
\end{tabular}

Only principal component with eigenvalues $>1$ and that explain $>5 \%$ of the total variance were presented.

See Table 1 for abbreviations.

abundance of ${ }^{15} \mathrm{~N}$, the values of all soil fractions ranged from $6.15 \%$ o to $8.25 \%$. The LF possessed the lowest $\delta^{15} \mathrm{~N}$ values among all sites, showing the same pattern as for $\delta^{13} \mathrm{C}$. All other fractions had higher $\delta^{15} \mathrm{~N}$ values than LF and exhibited an increasing tendency following the decrease of fraction size, with the silt and clay fraction being the most enriched. This variation pattern was the reverse of that observed with the $\mathrm{C} / \mathrm{N}$ ratios (Fig. 2B).

3.4. The relative significance of fraction parameters accounting for the changes induced by land use and management

The PCA was performed on the data matrix (forest sites as rows, and $\mathrm{C}$ and $\mathrm{N}$ related fraction parameters as columns) to assess the difference in SOM among the tested forest sites, screening for the most informative and unique physical parameters affected by land use and management. Only PCs with eigenvalues $>1$ that explained at least $5 \%$ of the total variance were retained for interpretation. Based on the information obtained from the analysis, all the variables are ranked with respect to the degree of variable importance (Table 2). In general, PC1, which accounted for $33.7 \%$ of the total variance, contrasted LF and macroaggregate associated $\mathrm{C}$ and $\mathrm{N}$ contents with other parameters. Ten parameters had significant loadings on PC1. Listed in order of decreasing significance are the nine positively weighted $\left(\mathrm{C}_{\mathrm{LF}}, \mathrm{N}_{\mathrm{LF}}, \mathrm{C}_{250-2000 \mu \mathrm{m}}, \mathrm{N}_{250-2000 \mu \mathrm{m}}, \mathrm{N}_{<53 \mu \mathrm{m}}, \mathrm{C}_{<53 \mu \mathrm{m}}, \delta^{15} \mathrm{~N}_{<53 \mu \mathrm{m}}\right.$, $\left.\delta^{15} \mathrm{~N}_{250-2000 \mu \mathrm{m}}, \delta^{15} \mathrm{~N}_{53-250 \mu \mathrm{m}}\right)$ and one negatively weighted $\left(\mathrm{C} / \mathrm{N}_{\mathrm{LF}}\right)$ parameters. PC2, which explained $16.5 \%$ of the total variance, included four significant, positively weighted parameters that reflected $\delta^{13} \mathrm{C}$ levels and one negatively weighted $\left(C / N_{<53} \mathrm{~mm}\right)$ parameters. Significant PC3, PC4 and PC5 loadings explained $14.7 \%, 13.9 \%$ and $6.8 \%$ of the total variance, respectively. PC3 reflected microaggregate associated SOM quantity, and microaggregate and macroaggregate associated SOM quality; PC4 reflected mainly the $\mathrm{C} / \mathrm{N}$ ratios in both the LF and macroaggregates as well as the $\delta^{13} \mathrm{C}$ and $\delta^{15} \mathrm{~N}$ levels in the LF, while PC5 only reflected the levels of $\delta^{15} \mathrm{~N}$. The ordination of forest sites were further plotted in two dimensions based on scores of PC1 and PC2, and PC3 and PC4 (Fig. 3). Distinct separations were found between the NF and the plantation sites, as well as among the plantation sites (1R, 2R-T and 2R-W) in PC1 and PC2 plot (Fig. 3A), and PC3 and PC4 plot (Fig. 3B), respectively.

Screening tests were also conducted to identify the sensitive fraction parameters accounting for the changes observed following different land uses and management practices. All the 20 fraction parameters (as independent variables), and 30 referred soil chemical and biological parameters (each as a dependent variable, grouped into five categories in the form of $\mathrm{C}$ pool, $\mathrm{N}$ pool, $\mathrm{N}$ transformation, and microbial diversity and soil respiration related indexes), were included in the stepwise regression analysis. This method retained five independent variables, the $\mathrm{C}$ and $\mathrm{N}$ contents of the macroaggregates, and $\mathrm{C}$ and $\mathrm{N}$ contents and $\mathrm{C} / \mathrm{N}$ ratio of the $\mathrm{LF}$, as the most sensitive and potential indices (Table 3 ). The macroaggregate associated $\mathrm{N}$ content can explain the variance of almost half of the dependent variables detected; and the variances of the remaining 16 dependent variables were explained by the $\mathrm{C}$ content of the macroaggregates, and $\mathrm{C}$ and $\mathrm{N}$ content and $\mathrm{C} / \mathrm{N}$ ratio of the LF. All the regression relationship of each model fitted the data well; the adjusted $R^{2}$ and $T$ values of the partial regression coefficients were highly significant, especially for those indicating the status of $\mathrm{C}$ pool, $\mathrm{N}$ pool and $\mathrm{N}$ transformation $(p<0.001)$.

\section{Discussion}

The three adjacent sites used for this study were located on the same position of the slope, had the same vegetative cover prior to the establishment of hoop pine plantations, and the soils were developed
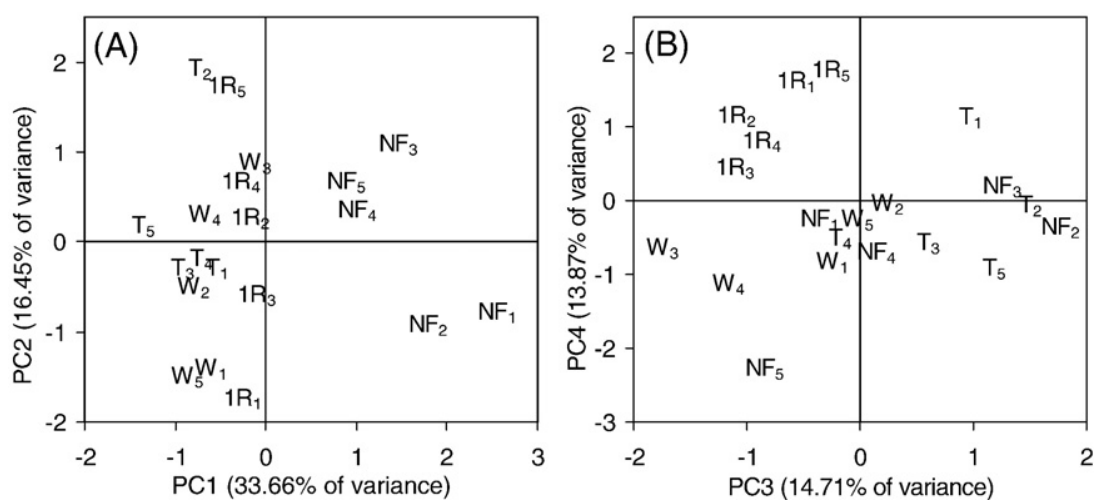

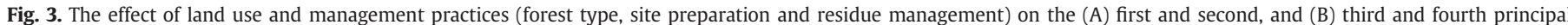

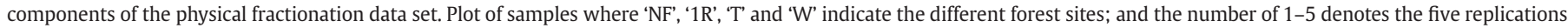

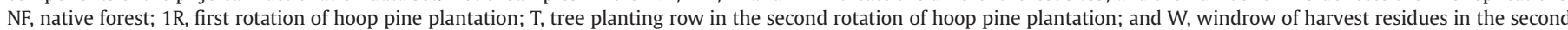
rotation of hoop pine plantation. 
Table 3

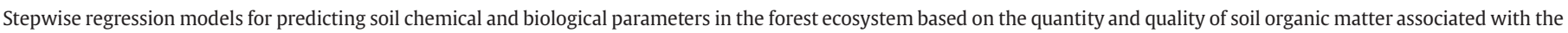
macroaggregates and light fractions

\begin{tabular}{|c|c|c|c|c|c|c|c|}
\hline \multirow[t]{3}{*}{ Soil chemical and biological parameters ${ }^{a}$} & \multirow[t]{3}{*}{ Model adjusted $R^{2}$} & \multirow[t]{3}{*}{ Equation intercept } & \multicolumn{5}{|c|}{ Partial regression slope } \\
\hline & & & \multicolumn{2}{|c|}{$250-2000 \mu \mathrm{m}$} & \multicolumn{3}{|l|}{ LF } \\
\hline & & & $\mathrm{C}$ & $\mathrm{N}$ & $\mathrm{C}$ & $\mathrm{N}$ & $\mathrm{C} / \mathrm{N}$ \\
\hline \multicolumn{8}{|l|}{ C pool } \\
\hline $\mathrm{C}_{\text {whole }}$ & $0.872^{* * *}$ & 7.08 & $1.29^{* * *}$ & & & & \\
\hline MBC & $0.772^{* * *}$ & -77.94 & & $388.36^{* * *}$ & & & \\
\hline $\mathrm{SOC}_{\mathrm{hw}}$ & $0.942^{* * *}$ & -264.21 & & $262.15^{* * *}$ & $62.29^{* * *}$ & & \\
\hline $\mathrm{SOC}_{\mathrm{hKCl}}$ & $0.904^{* * *}$ & -1046.22 & & $632.89^{* * *}$ & $125.12^{* *}$ & & \\
\hline $\mathrm{SOC}_{\mathrm{K}_{2} \mathrm{SO} 4}$ & $0.540^{* * *}$ & 596.79 & & & & & $-21.31^{* * *}$ \\
\hline \multicolumn{8}{|l|}{$\mathrm{N}$ pool } \\
\hline $\mathrm{N}_{\text {whole }}$ & $0.821^{* * *}$ & 0.34 & & $1.38^{* * *}$ & & & \\
\hline MBN & $0.663^{* * *}$ & 4.26 & $3.47^{* * *}$ & & & & \\
\hline $\mathrm{SON}_{\mathrm{hw}}$ & $0.951^{* * *}$ & -55.44 & & $28.90^{* * *}$ & & $32.06^{* * *}$ & \\
\hline $\mathrm{SON}_{\mathrm{hKCl}}$ & $0.869^{* * *}$ & -173.43 & & $94.31^{* * *}$ & & & \\
\hline $\mathrm{SON}_{\mathrm{K}_{2} \mathrm{SO} 4}$ & $0.549^{* * *}$ & 52.04 & & & & & $-1.85^{* * *}$ \\
\hline \multicolumn{8}{|l|}{$\mathrm{N}$ transformation } \\
\hline NMineral & $0.698^{* * *}$ & -1.71 & & $1.36^{* * *}$ & & & \\
\hline NNitri & $0.656^{* * *}$ & -4.04 & & $1.67^{* * *}$ & & & \\
\hline PPSON & $0.801^{* * *}$ & -37.16 & & $25.21^{* * *}$ & & & \\
\hline \multicolumn{8}{|l|}{ Biolog ${ }^{\mathrm{TM}}$ microbial diversity index } \\
\hline AWCD & $0.396^{* *}$ & 0.630 & & & & & $-0.022^{* *}$ \\
\hline SDI & $0.410^{* * *}$ & 4.638 & & & & & $-0.096^{* * *}$ \\
\hline \multicolumn{8}{|l|}{ Soil respiration } \\
\hline$R_{\text {bas }}$ & $0.461^{* * *}$ & 0.279 & & $0.157^{* * *}$ & & & \\
\hline SIR $_{\text {Arginine }}$ & $0.390^{* *}$ & -0.236 & & $0.089^{* *}$ & & & \\
\hline SIR $_{\text {Arabinose }}$ & $0.336^{* *}$ & -0.260 & & $0.104^{* *}$ & & & \\
\hline SIR $_{\text {Galabinose }}$ & $0.341^{* *}$ & 0.291 & & $0.104^{* *}$ & & & \\
\hline SIR Oxalic acid & $0.503^{* * *}$ & -0.309 & & $0.178^{* * *}$ & & & \\
\hline SIR $_{\text {Citric acid }}$ & $0.341^{* *}$ & 0.120 & $0.010^{* *}$ & & & & \\
\hline SIR $_{\text {Malic acid }}$ & $0.664^{* * *}$ & -0.518 & $0.016^{* * *}$ & & & & \\
\hline $\begin{array}{l}\text { SIR }_{\text {Acetylglic acosamine }} \\
\text { Sceslid }\end{array}$ & $0.194^{*}$ & 0.354 & $0.011^{*}$ & & & & \\
\hline SIR $_{\text {Lysine }}$ & $0.657^{* * *}$ & -0.087 & & & $0.043^{\text {*** }}$ & & \\
\hline SIR $_{\text {Glucose }}$ & $0.272^{*}$ & 0.401 & & & & $0.036^{*}$ & \\
\hline
\end{tabular}

***, ${ }^{* *},{ }^{*}$ significant at the $0.001,0.01$ and 0.05 probability level, respectively.

${ }^{\text {a }} \mathrm{C}_{\text {whole }} / \mathrm{N}_{\text {whole, }}$, total $\mathrm{C}$ and $\mathrm{N}$ of the whole soil, $\mathrm{mg} \mathrm{g}^{-1}$; MBC/MBN, soil microbial biomass $\mathrm{C}$ and $\mathrm{N}, \mathrm{mg} \mathrm{kg}^{-1} ; \mathrm{SOC}_{\mathrm{hw}} / \mathrm{SON}_{\mathrm{hw}}, 70{ }^{\circ} \mathrm{C}$ hot water extractable soluble organic $\mathrm{C}$ and $\mathrm{N}$,

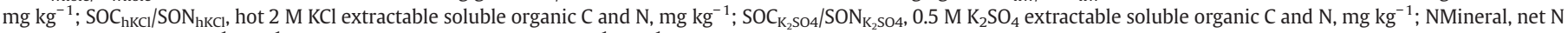

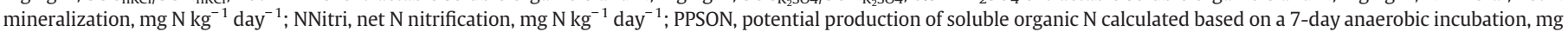

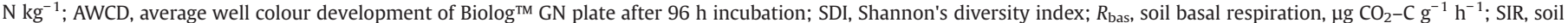
MicroResp ${ }^{\mathrm{TM}} \mathrm{C}$ source substrate induced respiration (for individual $\mathrm{C}$ substrates), $\mu \mathrm{g} \mathrm{CO}_{2}-\mathrm{C} \mathrm{g}^{-1} \mathrm{~h}^{-1}$; other abbreviations see Table 1 .

from the same basaltic parent material. As such, differences in SOM pools and chemical and biological properties among the sites are assumed to be the result of the land uses and forest management practices (Burton et al., 2007a).

4.1. Land use and management-induced changes within the tested forest sites as revealed by ANOVA and the results of $C$ and $N$ related parameters

Differences between the NF and the $1 \mathrm{R}$ soils may reflect the impact of the change in forest type and tree species, the ensuing difference in the quality of organic matter input, and changes in microclimate. Statistical ANOVA and paired t-test results in Table 1 revealed a significant effect of a shift from NF to $1 \mathrm{R}$ in forest type and rotation practices on the SOM pools. The major mechanism involved is thus likely to be the reduction in organic matter quality and litter quantity resulting from the conversion of the mixed species NF compared to the single-species plantation. The effects of disturbance and residue of previous harvests are also expected since these might occur during rotation of $1 \mathrm{R}$ hoop pine plantation from NF. The difference between $1 \mathrm{R}$ and $2 \mathrm{R}-\mathrm{T}$ plantations may reflect the short-term impact of rotation practices on SOM, including the effect of harvesting and disturbance during the 2R-T establishment and subsequent silvicultural practices, as well as the effect of closed and open canopy on soil temperature. It was found in the ANOVA results that rotation practices only showed the significant influence on SOM associated with the relatively labile fractions such as macroaggregates and LF (Table 1). Previous studies have shown that macroaggregates are sensitive to changes in SOM because these structures are dependent on live binding agents and generally do not exhibit long-term stability (Christensen, 2001; Six et al., 2004). Soil physical disturbance generally results in decreased macroaggregate stability and the release of relatively stable microaggregates, which may then become building blocks for the next cycle of macroaggregates formation (Six et al., 1999, 2000a,b). Given a definitely recent disturbance conducted at the $2 \mathrm{R}$ site (comparing to the aged effect of disturbance in $1 \mathrm{R}$ ) during the hoop pine rotation, the newly destruction of stable macroaggregates and the subsequent release of macroaggregates occluded microaggregates thus seemed to be one possible reason ascribing for the increase of microaggregate associated $\mathrm{C}$ observed in 2R-T. Additionally, the accelerated decomposition of the organic matter at the $2 \mathrm{R}-\mathrm{T}$ site with the early development in stand after canopy loss might be regarded as another key factor for the explanation of the lower $\mathrm{C}$ and $\mathrm{N}$ stocks associated with the macroaggregates and LF at the 2R-T plantation sites compared to the site under $1 \mathrm{R}$. Any differences between $2 \mathrm{R}-\mathrm{T}$ and $2 \mathrm{R}-\mathrm{W}$ may reflect the impact from residue management in $2 \mathrm{R}-\mathrm{W}$, as well as planting practices in $2 \mathrm{R}-\mathrm{T}$. One possible mechanism for the observed significant decreases of microaggregates associated $C$ and $\mathrm{N}$ at the $2 \mathrm{R}-\mathrm{W}$ site compared with the $2 \mathrm{R}-\mathrm{T}$ site is the increased organic matter decomposition. Rates of decomposition may increase due to elevated soil temperatures and/or more favourable soil moisture resulting from the residue cover at the $2 \mathrm{R}-\mathrm{W}$ site, and due to the absence of plant rhizosphere effect that may facilitate the 

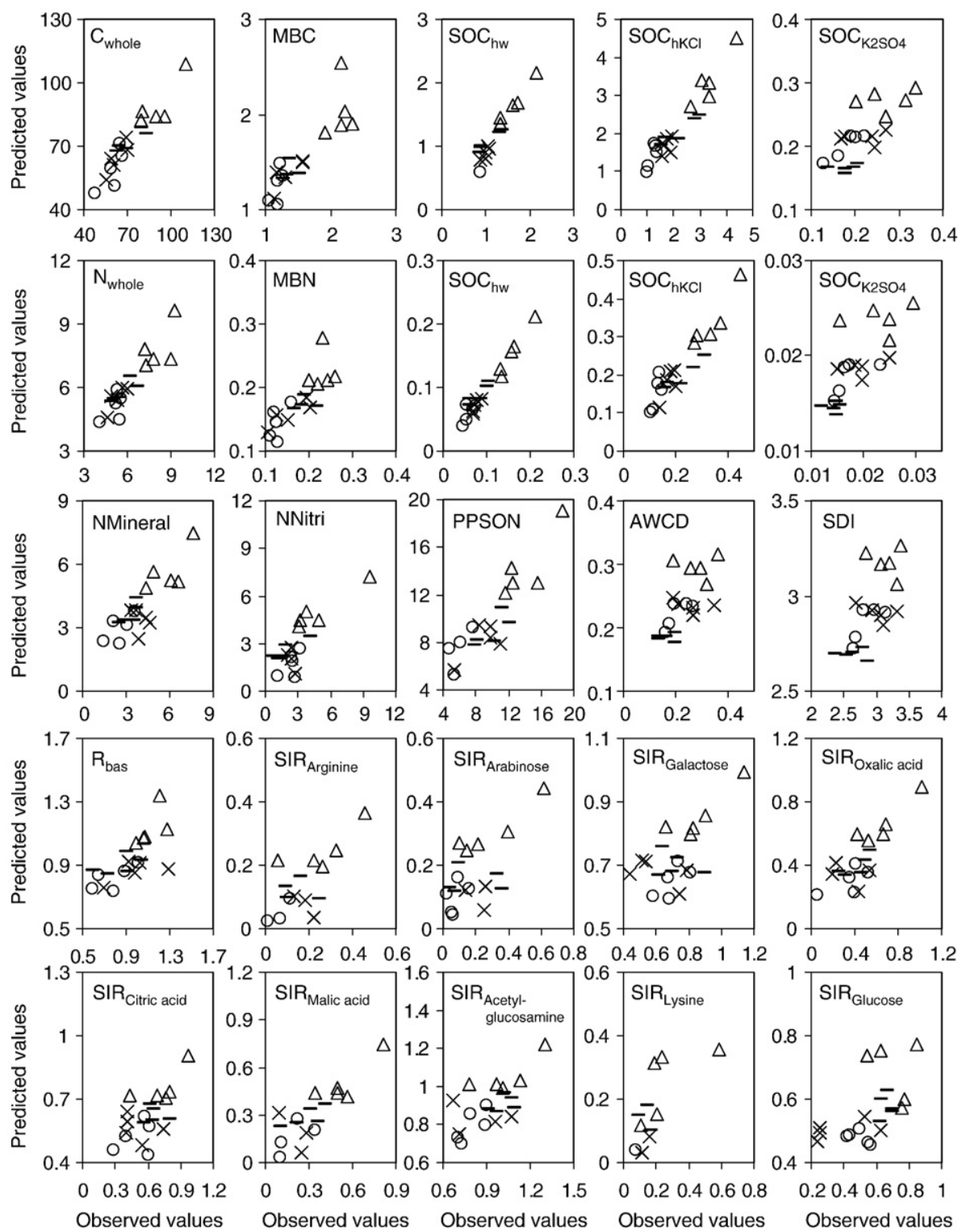

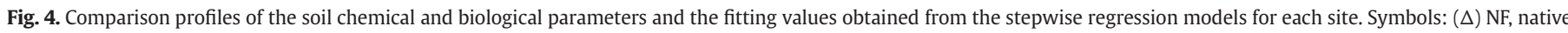

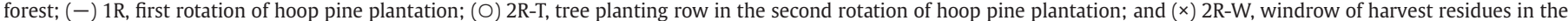

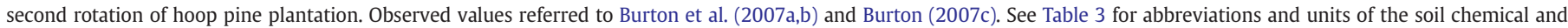
biological parameters.

microaggregation. However, no consistently significant effect emerged due to the young age and early development in stand in spite of the differences observed between the varied SOM fractions of these two $2 \mathrm{R}$ sites.

Allocation patterns of $\mathrm{C}$ and $\mathrm{N}$ among the soil fractions did not alter within the forest sites tested (Fig. 1). Macroaggregates had significantly higher $\mathrm{C}$ and $\mathrm{N}$ content than the microaggregates and silt and clay fraction, and increasing $\mathrm{C}$ and $\mathrm{N}$ stocks with increasing aggregate size were found in all soils. This is in agreement with the previous studies where macroaggregates have been reported to be more C-rich than microaggregates (Elliott, 1986; Guggenberger et al., 1999; Six et al., 2000a,b, 2001). Our results were also in line with the concept of aggregate hierarchy according to which microaggregates are bound together into macroaggregates by transient binding agents (i.e., microbial- and plant-derived polysaccharides) and temporary binding agents (roots and fungal hyphae) (Tisdall and Oades, 1982; Six et al., $2000 \mathrm{~b}$ ). The consequences of this aggregate hierarchy are an increase in C stock with increasing aggregate-size class because larger aggregate-size classes are composed of smaller aggregate-size classes plus organic binding agents (Elliott, 1986).

Using the $\mathrm{C} / \mathrm{N}$ ratio as an indicator of the degree of SOM decomposition, we found the same order of increasing degree of SOM degradation and humification in all fractions of all the sites examined: silt and clay fraction $<$ microaggregates $<$ macroaggregates $<$ LF. Oades et al. (1987) suggested that organic matter with $\mathrm{C} / \mathrm{N}$ ratios close to 20 is composed of plant materials in the early stages of decomposition. The wider C/N ratio (15.2-20.2) of LF, relative to other fractions, might thus suggest that these fractions derive mainly from plants, but with considerable microbial degradation and immobilization of $\mathrm{N}$ relative to fresh litter residues, which have typical $\mathrm{C} / \mathrm{N}$ ratios greater than 40 (Mathers et al., 2003). Meanwhile, the trend of relatively high C/N ratio in macroaggregates lends support to the idea that macroaggregates are held together by labile binding agents. Buyanovsky et al. (1994) found that macroaggregates had higher $\mathrm{C} / \mathrm{N}$ ratios than microaggregates, 
attributable to incompletely humified organic material, suggesting that active binding agents are root hairs and fungi. In contrast, they found lower $\mathrm{C} / \mathrm{N}$ ratios in microaggregates, indicative of organic matter that was more highly processed and persistent (Buyanovsky et al., 1994). As such, given that the second largest proportion (15.8-22.6\%) of whole soil $\mathrm{C}$ accumulated in the microaggregates, stabilization of $\mathrm{C}$ and $\mathrm{N}$ within this fraction possibly constitutes an important long-term sink for soil C and $\mathrm{N}$ in the ecosystem tested, since the microaggregates may have longer residence times as suggested by narrower $\mathrm{C} / \mathrm{N}$ ratios. The silt and clay fraction had the narrowest $\mathrm{C} / \mathrm{N}$ ratios, suggesting the most humified state and potentially the largest degree of microbial origin. The increasing degree of humification with decreasing fraction size accords with the results of many previous studies (Elliott, 1986; Oades et al., 1987; Beare et al., 1994; García-Oliva et al., 1994).

The natural abundance of ${ }^{15} \mathrm{~N}$ in soil fractions may also help elucidate the quality of SOM that has varied following land use and management changes. Controls on soil $\delta^{15} \mathrm{~N}$ values are complex and include the quantity and quality of SOM inputs, soil $\mathrm{N}$ sources, and isotopic fractionations resulting from $\mathrm{N}$ transformations (Nadelhoffer and Fry, 1988; Piccolo et al., 1994; Xu et al., 2003). Despite this complexity in the interpretation of $\delta^{15} \mathrm{~N}$ values, there are some generalities. Plant and litter inputs are generally less enriched in ${ }^{15} \mathrm{~N}$ relative to soil due to plant uptake of mineral $\mathrm{N}$ which is isotopically depleted compared to soil total N (Gebauer and Schulze, 1991; Handley and Raven, 1992). $\delta^{15} \mathrm{~N}$ values increase with increasing microbial transformation of residues in litter inputs since microbial discrimination of ${ }^{15} \mathrm{~N}$ occurs during $\mathrm{N}$-catabolic processes in the soil (Christensen, 1992). Thus, successive microbial decomposition of $\mathrm{N}-$ containing substrates results in the progressive increase in ${ }^{15} \mathrm{~N}$ of SOM (Kramer et al., 2003), that is, $\delta^{15} \mathrm{~N}$ tends to become enriched with increasing humification. Although $\delta^{15} \mathrm{~N}$ values hardly differed between the treatments and among the fractions (except for the difference in the LF induced by forest type changes) (Table 1), the consistent trend of more enriched $\delta^{15} \mathrm{~N}$ values in the silt and clay fraction and microaggregates relative to macroaggregates and LF which had lower $\delta^{15} \mathrm{~N}$ values were definitely found in all soils (Fig. 2B), suggesting that silt and clay fraction and microaggregate associated SOM may be not only physically protected, but also highly decomposed, humified and biochemically recalcitrant. These results are consistent with the findings based on the $\mathrm{C} / \mathrm{N}$ ratios discussed above.

4.2. The most informative and unique fractions accounting for the changes induced by land use and management

The PCA method provided five significant PCs that together explained about $86 \%$ of the total variance. As shown by Fig. 3, scores of PC1 on PCA plot separated NF from all the plantation sites, suggesting the influence of forest type shift (Fig. 3A). This possibly resulted mainly from the interactive controls of $\mathrm{C}$ and $\mathrm{N}$ contents associated with the LF and macroaggregates as suggested by the relatively high scores of these fraction parameters on PC1 (Table 2). PC3 and PC4 discriminated 1R, and to some extent 2R-T and 2R-W from each other as well, indicating the influence of the plantation in both ways of site preparation and residue management (Fig. 3B). Based on the scores of each responsible parameter on PC3 and PC4, it could thus be concluded that the 1R site with low PC3 and high PC4 scores, compared with $2 \mathrm{R}$ sites, might have better SOM quality associated with LF and macroaggregates since no harvest and site disturbance had been conducted recently. The 2R-W site with almost all the negative PC3 scores, compared to the 2R-T site with almost all the positive scores, might be ascribed to the decrease of $\mathrm{C}$ and $\mathrm{N}$ contents associated with the microaggregates, and to the increase of $\mathrm{C} / \mathrm{N}$ ratios associated with the macroaggregates and microaggregates after the residue management. However, all four sites showed no separation among the land uses and management practices in PC2 scores, explained by the $\delta^{13} \mathrm{C}$ related parameters. This was coincident with the results obtained in ANOVA of the $\delta^{13} \mathrm{C}$ values. The reason remains uncertain, but may be due to the unsuccessful detection of some possible changes of occluded aggregate associated $\delta^{13} \mathrm{C}$ within both the macroaggregates and microaggregates. Further study thus should aim to examine the subsequential fractionation of intraaggregates within macroaggregates and microaggregates. On the whole, the PCA identified that, of all the soil fractions, the LF and macroaggregates were the most informative and unique fractions affected by the land use and management changes.

Use of the $\mathrm{C}$ and $\mathrm{N}$ status of SOM fractions to elucidate the variation of the whole soil characteristics provides a means of screening for the sensitive indices that are candidates for indicating the soil process changes resultant from the land uses and management practices. From the stepwise regression models (Table 3), typical profiles of the soil chemical and biological parameters and the fitting values were paralleled (Fig. 4). In general, the variation of soil properties could be well predicted from the quantity and quality of SOM associated with the two relatively labile fractions (the macroaggregates and LF), especially from the $\mathrm{C}$ and $\mathrm{N}$ contents of the macroaggregates which were prevalent in the mass percentage, with the average fitting level of $80.6 \%, 77.1 \%, 71.8 \%$ and $41.4 \%$ (at least $p<0.05$ ) each for $\mathrm{C}$ pool, $\mathrm{N}$ pool, $\mathrm{N}$ transformation, and microbial diversity and respiration related indexes, respectively. There were closer correlations of the $\mathrm{C}$ and $\mathrm{N}$ stored in the macroaggregates and LF to TC and TN as compared to the correlation between the $\mathrm{C}$ and $\mathrm{N}$ in the microaggregates and silt and clay fraction to TC and TN. This suggests that the changed SOM storage was more closely associated with the macroaggregates and LF, and thus also demonstrates the reliability of the models established. Worth mentioning however, it is acknowledged that pseudo-replication is a limitation of this study and as such the experiment may be viewed as a case study. Whether or not these models could be extrapolated to other times and space samplings from the studied soil or to different soil types would need further investigation.

\subsection{Improving assessment for land use and management-induced changes}

Previous relevant studies have revealed that the LF and macroaggregate associated SOM represent the SOM pools with a short turnover time and are sensitive to changes in land use and management practices. In contrast, microaggregates, mineral-associated organic matter and organic matter entrapped at sites inaccessible to microbial attack or physically protected within soil aggregates belong to more stable organic matter pools with a turnover time from decades to centuries (Cambardella and Elliott, 1992; Christensen, 1992; Bremer et al., 1994; Franzluebbers and Arshad, 1997; Six et al., 1999; Puget et al., 2000; Helfrich et al., 2006). To our knowledge, the above general conclusions were drawn almost only based on the $\mathrm{C}$ and $\mathrm{N}$ distributions within SOM fractions. However, the overwhelming interactions of $\mathrm{C}$ and $\mathrm{N}$ in these fractions to soil chemical and biological processes induced by land use and management changes have yet been elucidated. In this study, by linking $C$ and $N$ distributions among SOM fractions with other multiple parameters reflecting important soil $\mathrm{C}$ and $\mathrm{N}$ dynamics, we constructed the interactive relationships between aggregate classes within SOM and soil chemical and biological processes, developing an improved assessment for land use and management-induced changes in soil under contrasting forest types, rotation practices and residue management.

\section{Conclusion}

Gaps within our knowledge on soil C and N distributions within SOM fractions and how $\mathrm{C}$ and $\mathrm{N}$ distributions within SOM fractions are related to land use and management-induced changes with respect to soil chemical and biological processes are identified and discussed in this case study. Fractionation of SOM demonstrated striking differences in $\mathrm{C}$ and $\mathrm{N}$ partitioning across the soil fractions of 
varying aggregate classes. Coupled with 30 soil chemical and biological parameters obtained in our previous studies, PCA and multivariable regression analysis suggested that the macroaggregates prevalent in the mass percentage and the labile LF with plant origin were more sensitive to the changes induced by the land uses and management practices compared with the other fractions. This study was a first step toward identifying the interactive relationships between aggregate classes within SOM and soil chemical and biological processes that underpin the land use and managementinduced changes in forest ecosystem.

\section{Acknowledgments}

We acknowledge the funding support from Australian Research Council. The joint support funding from National Natural Science Foundation of China (40425007, 40671092 and 20707020) and China Postdoctoral Science Foundation (20060400321) are also acknowledged. We would like to thank Dr. Rui Yin, Mr. Yu Huang, Ms. Elizabeth Bridon and Mr. Stephen Faggotter for their assistance in soil sampling and processing. We also thank Prof. Hossein Ghadiri for providing the wet-sieving machine, Mr. Rene Diocares for technical assistance and Ms. Marijke Heenan for experimental preparation help.

\section{References}

Beare, M.H., Cabrera, M.L., Hendrix, P.F., Coleman, D.C., 1994. Aggregate-protected and unprotected organic matter pools in conventional- and no-tillage soils. Soil Sci. Soc. Am. J. 58, 787-795.

Blumfield, T.J., Xu, Z.H., Mathers, N.J., Saffigna, P.G., 2004. Decomposition of nitrogen-15 labeled hoop pine harvest residues in subtropical Australia. Soil Sci. Soc. Am. J. 68, 1751-1761.

Bremer, E., Jansen, H.H., Johnston, A.M., 1994. Sensitivity of total, light fraction and mineralizable organic matter to management practices in a Lethbridge soil. Can. J. Soil Sci. 74, 131-138.

Burton, J., Chen, C.R., Xu, Z.H., Ghadiri, H., 2007a. Gross nitrogen transformations in adjacent native and plantation forests of subtropical Australia. Soil Biol. Biochem. 39, 426-433.

Burton, J., Chen, C.R., Xu, Z.H., Ghadiri, H., 2007b. Soluble organic nitrogen pools in adjacent native and plantation forests of subtropical Australia. Soil Biol. Biochem. $39,2723-2734$.

Burton, J., 2007c. Soil nitrogen dynamics under adjacent native forest and hoop pine plantations. Ph.D. Thesis, Griffith University, Nathan, Queensland, Australia, 68-94pp.

Buyanovsky, G.A., Aslam, M., Wagner, G.H., 1994. Carbon turnover in soil physical fractions. Soil Sci. Soc. Am. J. 58, 1167-1173.

Cambardella, C.A., Elliott, E.T., 1992. Particulate soil organic matter changes across a grassland sequence. Soil Sci. Soc. Am. J. 56, 777-783.

Cambardella, C.A., Elliott, E.T., 1993. Carbon and nitrogen mineralization in aggregates from cultivated and native grassland soils. Soil Sci. Soc. Am. J. 57, 1071-1076.

Campbell, C.D., Chapman, S.J., Cameron, C.M., Davidson, M.S., Potts, J.M., 2003. A rapid microtiter plate method to measure carbon dioxide evolved from carbon substrate amendments so as to determine the physiological profiles of soil microbial communities by using whole soil. Appl. Environ. Microb. 69, 3593-3599.

Cattell, R.B., 1966. The scree test for the number of factors. Multivar. Behav. Res. 1, 245-276.

Chen, C.R., Condron, L.M., Davis, M., Sherlock, R., 2000. Effects of afforestation on phosphorus dynamics and biological properties in a New Zealand grassland soil. Plant Soil 220, 151-163.

Chen, C.R., Xu, Z.H., Mathers, N.J., 2004. Soil carbon pools in adjacent natural and plantation forests of subtropical Australia. Soil Sci. Soc. Am. J. 68, 282-291.

Chen, C.R., Xu, Z.H., Keay, P., Zhang, S.L., 2005. Total soluble nitrogen in forest soils as determined by persulfate oxidation and by high temperature catalytic oxidation. Aust. J. Soil Res. 43, 515-523.

Christensen, B.T., 1992. Physical fractionation of soil and organic matter in primary particle size and density separates. Adv. Soil Sci. 20, 1-90.

Christensen, B.T., 2001. Physical fractionation of soil and structural and functional complexity in organic matter turnover. Eur. J. Soil Sci. 52, 345-353.

Echeverría, M.E., Markewitz, D., Morris, L.A., Hendrick, R.L., 2004. Soil organic matter fractions under managed pine plantations of the southeastern USA. Soil Sci. Soc. Am. J. 68, 950-958.

Elliott, E.T., 1986. Aggregate structure and carbon, nitrogen, and phosphorous in native and cultivated soils. Soil Sci. Soc. Am. J. 50, 627-633.

Franzluebbers, A.J., Arshad, M.A., 1997. Soil microbial biomass and mineralizable carbon of water-stable aggregates. Soil Sci. Soc. Am. J. 61, 1090-1097.

García-Oliva, F., Casar, I., Morales, P., Maass, J.M., 1994. Forest-to-pasture conversion influences on soil organic matter dynamics in a tropical deciduous forest. Oecologia 99, 392-396.

Gebauer, G., Schulze, E.D., 1991. Carbon and nitrogen isotope ratios in different compartments of a healthy and a declining Picea abies forest in the Fichtelgebirge NE Bavaria. Oecologia 87, 198-207.
Gianello, C., Bremner, J.M., 1986. A simple method of assessing potentially available organic nitrogen in soil. Commun. Soil Sci. Plant Anal. 17, 195-214.

Gregorich, E.G., Beare, M.H., McKim, U.F., Skjemstad, J.O., 2006. Chemical and biologica characteristics of physically uncomplexed organic matter. Soil Sci. Soc. Am. J. 70, 975-985.

Guggenberger, G., Elliott, E.T., Frey, S.D., Six, J., Paustian, K., 1999. Microbial contributions to the aggregation of a cultivated grassland soil amended with starch. Soil Biol. Biochem. 31, 407-419.

Handley, L.L., Raven, J.A., 1992. The use of natural abundance of nitrogen isotopes in plant physiology and ecology. Plant Cell Environ. 15, 965-985.

Hart, S.C., Stark, J.M., Davidson, E.A., Firestone, M.K., 1994. Nitrogen mineralisation, immobilisaton and nitrification. Methods of soil analysis. In: Weaver, R. (Ed.), Part 2: Microbiological and Biochemical Properties. Soil Science Society of America. Madison, Wisconsin, pp. 985-1018.

Helfrich, M., Ludwig, B., Buurman, P., Flessa, H., 2006. Effect of land use on the composition of soil organic matter in density and aggregate fractions as revealed by solid-state ${ }^{13} \mathrm{C}$ NMR spectroscopy. Geoderma 136, 331-341.

Jastrow, J.D., 1996. Soil aggregate formation and the accrual of particulate and mineralassociated organic matter. Soil Biol. Biochem. 28, 665-676.

Johnson, D.W., Curtis, P.S., 2001. Effects of forest management on soil C and $\mathrm{N}$ storage: meta analysis. Forest Ecol. Manag. 140, 227-238.

Jolivet, C., Arrouays, D., Lévèque, J., Andreux, F., Chenu, C., 2003. Organic carbon dynamics in soil particle-size separates of sandy Spodosols when forest is cleared for maize cropping. Eur. J. Soil Sci. 54, 257-268.

Kaiser, H.F., 1960. The application of electronic computers to factor analysis. Educ. Psychol. Meas. 29, 141-151.

Kramer, M.G., Sollins, P., Sletten, R.S., Swart, P.K., 2003. N isotope fractionation and measures of organic matter alteration during decomposition. Ecology 84, 2021-2025.

Ladd, J.N., Foster, R.C., Skjemstad, J.O., 1993. Soil structure: carbon and nitrogen metabolism. Geoderma 56, 401-434.

Lützow, M.V., Kögel-Knabner, I., Ekschmitt, K., Flessa, H., Guggenberger, G., Matzner, E. Marschner, B., 2007. SOM fractionation methods: relevance to functional pools and to stabilization mechanisms. Soil Biol. Biochem. 39, 2183-2207.

Marriott, E.E., Wander, M.M., 2006. Total and labile soil organic matter in organic and conventional farming systems. Soil Sci. Soc. Am. J. 70, 950-959.

Mathers, N.J., Xu, Z.H., Blumfield, T.J., Berners-Price, S.J., Saffigna, P.G., 2003. Composition and quality of harvest residues and soil organic matter under windrow residue management in young hoop pine plantations as revealed by solidstate ${ }^{13} \mathrm{C}$ NMR spectroscopy. Forest Ecol. Manag. 175, 467-488.

Nadelhoffer, K.J., Fry, B., 1988. Controls on natural nitrogen-15 and carbon-13 abundances in forest soil organic matter. Soil Sci. Soc. Am. J. 52, 1633-1640.

Ni, J.Z., Xu, J.M., Xie, Z.M., Wang, D.J., 2004. Changes of labile organic carbon fractions in soils under different rotation systems. Pedosphere 14, 103-109.

Oades, J.M., Vassallo, A.M., Waters, A.G., Wilson, M.A., 1987. Characterization of organic matter in particle size and density fractions from red-brown earth by solid-state ${ }^{13} \mathrm{C}$ NMR. Aust. J. Soil Res. 25, 71-82.

O'Brien, N.D., Attiwill, P.M., Weston, C.J., 2003. Stability of soil organic matter in Euca lyptus regnans forests and Pinus radiata plantations in southeastern Australia. Forest Ecol. Manag. 185, 249-261.

Piccolo, M.C. Neill, C. Cerri, C.C. 1994. Natural abundance of ${ }^{15} \mathrm{~N}$ in soils along forest-topasture chronosequences in the western Brazilian Amazon Basin. Oecologia 99,112-117.

Puget, P., Chenu, C., Balesdent, J., 2000. Dynamics of soil organic matter associated with particle-size fractions of water-stable aggregates. Eur. J. Soil Sci. 51, 595-605.

Sá, J.C.de.M., Cerri, C.C., Dick, W.A., Lal, R., Filho, S.P.V., Piccolo, M.C., Feigl, B.E., 2001 Organic matter dynamics and carbon sequestration rates for a tillage chronosequence in a Brazilian Oxisol. Soil Sci. Soc. Am. J. 65, 1486-1499.

Six, J., Elliott, E.T., Paustian, K., 1999. Aggregate and soil organic matter dynamics under conventional and no-tillage systems. Soil Sci. Soc. Am. J. 63, 1350-1358.

Six, J., Elliott, E.T., Paustian, K., 2000a. Soil macroaggregate turnover and microaggregate formation: a mechanism for $\mathrm{C}$ sequestration under no-tillage agriculture. Soil Biol. Biochem. 32, 2099-2103.

Six, J., Paustian, K., Elliott, E.T., Combrink, C., 2000b. Soil structure and organic matter. I. Distribution of aggregate-size classes and aggregate associated carbon. Soil Sci. Soc. Am. J. 64, 681-689.

Six, J., Guggenberger, G., Paustian, K., Haumaier, L., Elliott, E.T., Zech, W., 2001. Sources and composition of soil organic matter fractions between and within soil aggregates. Eur. J. Soil Sci. 52, 607-618.

Six, J., Callewaert, P., Lenders, S., De Gryze, S., Morris, S.J., Gregorich, E.G., Paul, E.A., Paustian, K., 2002. Measuring and understanding carbon storage in afforested soils by physical fractionation. Soil Sci. Soc. Am. J. 66, 1981-1987.

Six, J., Bossuyt, H., Degryze, S., Denef, K., 2004. A history of research on the link between (micro)aggregates, soil biota, and soil organic matter dynamics. Soil Tillage Res. 79 7-31.

Soil Survey Staff, 1999. Soil Taxonomy-A Basic System of Soil Classification for Making and Interpreting Soil Surveys. USDA Soil Conservation Service, Washington DC. 600 pp.

Tan, Z., Lal, R., Owens, L., Izaurralde, R.C., 2007. Distribution of light and heavy fractions of soil organic carbon as related to land use and tillage practice. Soil Tillage Res. 92, 53-59.

Tisdall, J.M., Oades, J.M., 1982. Organic matter and water-stable aggregates. J. Soil Sci. 33, 141-163.

Vance, E.D., Brookes, P.C., Jenkinson, D.S., 1987. An extraction method for measuring microbial biomass carbon. Soil Biol. Biochem. 19, 253-258.

Vesterdal, L., Ritter, E., Gundersen, P., 2002. Change in soil organic carbon following afforestation of former arable land. Forest Ecol. Manag. 169, 137-147.

Wander, M.M., Bidart, M.G., 2000. Tillage practice influences on the physical protection, bioavailability and composition of particulate organic matter. Biol. Fertil. Soils 32, 360-367. 
Wang, W.J., Smith, C.J., Chalk, P.M., Chen, D., 2001. Evaluating chemical and physica indices of nitrogen mineralisation capacity with an unequivocal reference. Soil Sci. Soc. Am. J. 65, 368-376.

Widmer, F., Fließbach, A., Laczkó, E., Schulze-Aurich, J., Zeyer, J., 2001. Assessing soil biological characteristics: a comparison of bulk soil community DNA-, PLFA-, and Biolog ${ }^{\mathrm{TM}}$-analyses. Soil Biol. Biochem. 33, 1029-1036.

$\mathrm{Xu}, \mathrm{Z} . \mathrm{H}$., Chen, C.R., 2006. Fingerprinting global climate change and forest management within rhizosphere carbon and nutrient cycling processes. Environ. Sci. Pollut. Res. 13, 293-298.
Xu, Z.H., Prasolova, N.V., Lundkvist, K., Beadle, C., Leaman, T., 2003. Genetic variation in carbon and nitrogen isotope composition and nutrient concentration in the foliage of 10 -year-old hoop pine families in relation to tree growth in subtropical Australia. Forest Ecol. Manag. 186, 359-371. 